\title{
RESEARCH PROCEEDINGS
}

\section{The Comparative Advantages of Single and Multi-Stakeholder Cooperatives: Reflections for a Research Agenda}

\section{ABSTRACT}

Multi-stakeholding is a way to share, or democratise, decision-making power among stakeholders within organisations. Analysis, however, has not fully considered the role of this form of private governance. This paper builds on the observation of past and recent governance experiences in cooperative firms, where sharing decision-making power was associated with single stakeholdership. Though single stakeholdership seemed to be the preferred solution so far, recently multi-stakeholder governance has become more prominent also in cooperatives. In light of this evidence, this paper has three aims. The first is to set out some of the theoretical arguments for and against multi-stakeholder governance, to look at examples of multi-stakeholder models in practice, and to generate from this a set of research questions. A useful distinction to assess how multi-stakeholdership can be applied in practice is between ownership and strategic control. We then use this distinction to present examples taken from the experiences of Eroski (the big Iberian retailer), iCoop (the Korean cooperative that brings together farmers and consumers), and Italian social cooperatives, which place the desirability of multi-stakeholding as one of their constitutional features. Our conclusions emphasise the necessity of improving this field of enquiry by outlining a research agenda on multi-stakeholder cooperatives.

\section{KEY-WORDS}

\section{COOPERATIVE GOVERNANCE, ORGANISATIONAL DESIGN}

\section{Acknowledgments}

We would like to thank participants in the ICA conference held in Stirling, Scotland, on June 20-23, 2017, where a version of this paper was first presented. Our thanks go also to Carlo Borzaga and Ermanno Tortia for constant discussion on the topic. Usual disclaimers apply.

JEL Classification: D23, P13, L20, L31 | DOI: http://dx.doi.org/10.5947/jeod.2018.011 


\section{Introduction}

When cooperatives were first invented, it was assumed their ownership would be limited to one stakeholder only. The Rochdale Pioneers favoured consumers, Schulze Delitsch and Raiffeisen farmers, Buchez workers, and so on. It is true that before these familiar types of cooperation crystallised, there was a period of idealism, when utopian socialists such as Robert Owen and Charles Fourier were advocating a cooperative community in which ownership would be much more holistic. Their vision did not survive much contact with reality, whereas cooperative stores for consumers prospered. There was also sometimes a period of confusion, when promoters were unsure about which stakeholder to put at the centre of the cooperative. William King set up cooperative stores that were both consumer and producer owned (with artisans bringing goods to sell through them), until it was realised that their interests could clash (Birchall, 1994). Raiffeisen set up rural banks in which investors had ownership rights, until he realised that they had to be owned by the farmers (Birchall, 2013). The emergence of single stakeholder cooperatives could be seen as a process of organisational evolution; every other type failed to survive and reproduce itself over time.

Ownership and governance are not always the same thing. Consumer cooperatives often reserve some places on their boards for employee representatives, while making sure that they are always in a small minority. Insurance mutuals have mainly expert boards, but have a tradition that a majority of board members should represent policyholders (Birchall, 2011). Housing cooperatives have also developed rules that ensure a majority of residents on their boards. Some farmer cooperatives have recently appointed one or two experts to their boards, but others are resisting the idea (Birchall, 2014).

Why, then, should we want to discuss the idea of multi-stakeholder ownership and governance of cooperatives? It is because practices are changing. Occasionally dual stakeholder cooperatives have been designed. The Spanish health cooperative Espriu has both doctors and patients on some of its boards. Eroski, the big Spanish retailer, has both consumer and worker members with ownership rights and an equal share in governance. iCoop in Korea has both consumers and farmers on its board. Recently, Italian social cooperatives have developed a model in which governance is open to more than one of the relevant stakeholders. Practice varies, but membership is open to some combination of workers, volunteers, other non-profit organisations and service users. The social cooperative sector is growing and being copied elsewhere. However, it operates typically in social care services where non-profits have traditionally provided services under contract to local authorities, and so it may or may not have more general applicability.

In light of the recent developments exemplified above, this paper has three aims: (i) to set out some of the theoretical arguments for and against multi-stakeholder ownership and governance; (ii) to describe some examples of multi-stakeholder models in practice; and (iii) to generate from this a set of research questions. 


\section{Economic theory and the assumption of single-stakeholder ownership}

Mainstream economic theory lends weight to the argument that multi-stakeholder ownership will not work. Since the seminal work by Jensen and Meckling (1976), agency theory has highlighted that when ownership and control do not overlap, there are costs attached to divergent interests between owners and controllers, where the latter refers typically to management. In a small business where the owners carry out the tasks of management and oversight themselves, there is no need for a separate governance function. As soon as they appoint a separate group of managers to run the business, the problem emerges of how the principals (the owners) can control the agents (the managers) so that their interests are aligned and managers do not engage in "rent-seeking" behaviour. Governance is seen as a cost to the business rather than an activity that adds value. Transaction cost economics adds to this analysis with two propositions. First, if giving ownership rights to a particular stakeholder group leads to high cost of governance compared with those of their competitors, the business and its members will suffer. If a change of ownership type reduces such costs, then eventually (other things being equal) it will be chosen. Conversions-such as from consumer to investor ownership, or from investor-ownership to employee ownership-can be explained in this way.

Second, there are also costs from not bringing a particular stakeholder group into ownership. Conventionally, if the cooperation of non-owner stakeholders is needed by the business, it is secured through contracts, the cost of which is determined through the market. For instance, the conventional capitalist solution is to have investor-owners and to contract with employees through paying them wages. However, there are circumstances where other type of ownership will be promoted. For instance, if an industry is prone to monopoly over crucial parts of the value chain, producer-ownership will prove more attractive than investor-ownership. This explains the popularity of farmer cooperatives (Hansmann, 1996).

What economic theory does not predict-in fact, does not even consider-is the possibility that more than one stakeholder group could take ownership (Sacchetti and Borzaga, 2017). It is assumed that stakeholder groups have essentially different interests that can only be brought into alignment through market contracting. If they are brought into ownership, then their interests have to be aligned through the system of governance. Since the costs of such governance will be too high (relative to competitors who do not need to incur such costs), the business will suffer.

To disentangle the puzzle of multi-stakeholding we need to consider that since governance is about strategic control, and since ownership is only one possible way to obtain actual strategic control, ownership and control need to be treated separately. In 1974, Zeitlin argued that the principal governance function (i.e. decision-making on strategic issues) is exerted by those who hold strategic control on the organisation, with or without ownership (or, as corporate governance studies emphasise, in excess of ownership, for example when voting share premiums are attached to stocks that carry a disproportionate amount of voting rights [cf. Zingales, 1995]). This argument was earlier introduced in 1932 by Berle and Means, and utilised in critical international business 
studies to highlight the uneven development effects of the concentration of strategic control within corporate hierarchies (Hymer, 1972; Cowling and Sugden, 1998).

For the governance of cooperatives, this analysis implies that the strategic goals of a cooperative are tied to the interests of the stakeholders holding control, and that extending ownership rights is not the only modality for extending strategic control. For instance, ownership rights and strategic control do not overlap when diverse owner types (such as minority and majority shareholders, small and large farmers/users; old and new member workers) share uneven degrees of representation in strategic decision-making bodies. The mismatch between ownership and control also occurs when management cannot be monitored or is not made accountable to all owners (Kirkpatrick, 2009).

If the advocates of multi-stakeholding want to bring other stakeholders into the business, they do not need to do this through giving them ownership rights but, arguably, can achieve the same end by enlarging the area of strategic control. They can also consider other governance solutions, such as representation in decision-making bodies that do or do not require ownership. To this end, for instance, Sacchetti and Borzaga (2017) utilize an extended idea of membership rather than ownership, where membership is broadly understood as stakeholder involvement in the strategic control or governing function of the organisation, with or without ownership.

For the management, the implication of enlarged control rights is that multiple categories of patrons (rather than a single category) can demand a justification of the management's action. At the same time, managers' extended fiduciary duty empowers managers to include a wide set of interests in strategic decisions. As we illustrate later in the paper, this is particularly relevant in the cases of iCoop in Korea, and the Italian social cooperatives.

\section{A strong argument for multi-stakeholder cooperatives}

Shann Turnbull has developed a strong argument for joint ownership and governance by employees, consumers and suppliers. Such a cooperative would have three separate boards to represent these interest groups, and they would together make up a compound board. He calls this "distributed control".

His argument against single-stakeholder ownership has three parts. First, centralised control is corrupting. Directors have too much power to maintain their positions while obtaining private benefits for themselves. Second, there is a lack of information by which board members can challenge the status quo. There is a lack of independent feedback information on performance. Directors become "largely captive to the information provided by management" (Turnbull, 2001: 178). Third, there is information overload, which means that directors cannot effectively process the information they need.

All these criticisms of unitary boards are familiar and we do not need much convincing of their merit. However, the mainstream literature on governance also sets out to tackle these problems, seeing them not as inherent to unitary governance but as faults that can be rectified. What Turnbull advocates 
is a complete redesign of businesses and we need to be convinced that his solution does not just produce another set of problems. At the heart of his solution is the introduction of greater complexity into the governance system, with boards being accountable to a higher authority that contains all the stakeholder interests. This is variously known as a supervisory board, stakeholder council, or watchdog board. Of course, this kind of design is also common in single stakeholder cooperatives. Multistakeholding adds the challenge of reconciling diverse interests before they reach the main board as well as enabling them to come together again at a higher level to supervise the board.

There remains the question of how the interests of such a diverse group of stakeholders can be reconciled. Much of the time they will have a common interest in the effective running of the business, but there must be moments when they have to decide who gets what from the value added. They cannot all benefit equally or all the time, nor can they always be expected to agree on what is fair. Another issue concerns the examples that are given of distributed ownership in practice. Turnbull lists the Japanese Keiretsu, employee-owned firms and the Mondragón cooperatives. The Keiretsu are a good example; here the firm distributes shares to employees and suppliers in order to bind them into the business. It could be described as "distributive capitalism" in that it widens the ownership of firms. Also, because firms invest in each other, it creates an informal business network. What is unclear is whether employees and suppliers benefit from increased complexity in the governance structure; this would depend on the extent of their shareholding in any one firm and on whether they are incentivised to make the most of this.

Employee-owned firms are not a good example of multi-stakeholding as they are either singlestakeholder cooperatives (if 100\% owned by employees) or hybrids (if majority owned by employees along with other investors). A firm that is owned by a combination of workers and investors is a kind of multi-stakeholding or at least "dual stakeholding", but some commentators see this as an unstable mix that should be encouraged to lead to full employee-ownership (Ellerman, 1990).

There are other examples of producer cooperative hybrids. Some food processing companies are now owned by a mix of farmers and outside investors. Kerry Group is a good example, though the farmer stakeholding has fallen recently to just $1 \%$. Other food processing companies are majority owned by farmers (Emmi in Switzerland is a good example), but in some cases the farmers have bought back their side of the business because they do not like sharing control with other investors. In Ireland, Lakeland Co-operative and Glanbia Co-operative have succeeded in buying back their dairying business. The only strong argument for a mix of producer and investor ownership is the need for more capital that outside shareholders can provide (Briscoe, McCarthy and Ward, 2012).

The Mondragón system is quite a good example of multi-stakeholding. At the level of the individual cooperative, most are still conventionally owned either by workers, consumers or farmers, but they have a tradition of inviting representatives from neighbouring cooperatives on to their boards. Also, at the higher level of the Corporation there are elaborate governance mechanisms for ensuring the different types of cooperative are represented. Also, at Mondragón there is one genuine worker and consumer owned retailer in the Group, Eroski (the Spanish cooperative retailer Consum has a similar ownership structure). 
There are a few other interesting examples of multi-stakeholder ownership that might support Turnbull's argument. iCoop is a very successful consumer-farmer owned cooperative federation in Korea which we will examine in more detail below. There are two health cooperative federations that have both producers (medical doctors) and consumers (people insured through health plans) on some of their boards: Unimed in Brazil, and Espriu in Spain (Birchall, 2014). However, in both these cases the producer interest predominates. A cynical view might be that the development of health plans is a way that medical doctors can gain business for themselves, and that having some consumers on the board is a necessary part of their legitimation. In practice, though, there is no reason for such cynicism; the common interest of both producer and consumer in having an effective health care system does seem to hold them together. On the other hand, the dominance of the medical interest coexisting with strong information asymmetries between doctors and patients is evidenced by the fact that government legislation has also been necessary to ensure the consumer interest is properly safeguarded in the governance of their health insurance mutuals.

We will now look further at two clear examples of multi-stakeholding-Eroski and iCoopbefore examining in some detail the most well-known example of the Italian social cooperatives.

\section{The examples of Eroski and iCoop}

Eroski is a supermarket chain that began in 1969 in the Basque region, with the merger of ten consumer cooperatives, but has now spread out into other parts of Spain and France. It is a highly successful business, with 1,896 stores (including supermarkets, super stores, cash \& carry, opticians, travel agents, perfume stores and sports shops) and an annual turnover of more than EUR 6 billion (Eroski, 2015). It has 33,509 employees and over seven million customer members, and is a member of the Mondragón Corporation.

Eroski's governance system is a hybrid of the Mondragón worker ownership system and of a conventional consumer cooperative; it describes itself as a consumer cooperative in which the workers are owners and the consumers are members. However, in order to become an owner an employee has to invest a significant amount in the cooperative; only 11,858 are "worker partners" out of a total of 33,509 workers. The "client partners" are a much higher proportion of the customers, accounting for $76 \%$ of sales. The incentives are very different: worker-owners share $40 \%$ of the profits, while consumer members receive discounts on purchases.

The annual general meeting consists of 250 worker and 250 consumer representatives, who then elect a governing board of six worker and six consumer partners. This governance system is supplemented by worker self-management in the stores and by 21 consumerist committees that provide guidelines for the cooperative. It is interesting that the president of the cooperative has to be a consumer rather than a worker member; anecdotally, the view of commentators who know the business is that the worker interest tends to dominate. This is only to be expected, since the workers 
have a much larger stake in the business, both as employees and as shareholders.

iCoop is also a successful retailer, with 180 stores and 17 factories for farm produce. At first sight, it is a similar mix of consumer and producer ownership (the producers being local farmers). Its 2015 annual report says it has 237,000 consumers and 2,367 producers in membership. However, it is not a primary but a secondary cooperative; the individual consumers and workers are grouped in 85 consumer and 33 producer cooperatives. It puts the emphasis on the consumption side of the equation, describing itself as a "consumer cooperative federation" of "consumer members who practice ethical consumption and production with producers" (iCoop, 2015). It owns a Mutual Aid Society for Enhancing Korean Agriculture that has business with consumers, producers and employees, but this is an insurance mutual so that its customers are all simply insured persons. The farmers are grouped into an association of producer groups.

The problem of how to reach a price for products is therefore solved within the market. The federation supplements this with a member account fund in which consumers make advance payments so that farmers can grow their produce without having to go into debt. It also has a price stabilisation fund that intervenes to smooth out farm prices over the year. The federation enables a genuine solidarity to be expressed between consumers and producers, but it keeps them separate so that their interests do not have to be completely reconciled.

\section{The Italian model of social cooperatives}

Organisations that provide social care for vulnerable people have a particular problem. Those who they are caring for include people with learning difficulties, people who are physically or mentally disabled, older people suffering from dementia and so on. They cannot always be relied on to look after their own interests either as purchasers of care or within the governance system of the cooperative. In economic theory, we might say the costs of both contracting and of governance are too high. This problem was analysed by Hansmann (1996), who recognised a dilemma. On the one hand, agency costs would be exceptional if users had to own the firm. On the other hand, there would be a clear disadvantage from being excluded. Hansmann's solution is that the organisation should be constituted as a non-profit in which nobody owns the enterprise and a board of trustees provides its governance. The trustees are trusted to act on behalf of the service users.

To date, a variety of governance solutions has been observed for organisations with social objectives (Young and Lecy, 2014; Defourny and Nyssens, 2017). A pioneering solution was the one introduced in Italy in 1991 for the social cooperative model (Law 381/1991). This model was explicitly engineered to be multi-stakeholder. Here the service users have the right to be part of the assembly of members and represented in the governance structure along with all the other main stakeholders: workers, volunteers, carers, other legal entities such as cooperatives and financial members. The inclusion of multiple stakeholders was formalised with subsequent laws (in 2006 
and 2017), introducing the social enterprise as distinct (but not inconsistent) from the cooperative model (see Fici, 2018).

Multi-stakeholding requires specific governance solutions and has implications for governance costs (Sacchetti and Tortia, 2014). At the same time, however, it enables the inclusion of a plurality of interests which can lower the costs of coordinating transactions on the market (borne by the internal patrons), but also the external costs associated with the exclusion of stakeholders from the governance process (borne by excluded stakeholders) (Borzaga and Sacchetti, 2015).

For the law: "Social cooperatives are intended to pursue the general interest of the community to human promotion and social integration of citizens through: (a) the management of social, health and educational services [Type A]; (b) carrying out various activities — agricultural, industrial, commercial or services_aimed at providing employment for disadvantaged persons [Type B]" (Italian Parliament, L. 381/1991; Art. 1) ${ }^{1}$.

Together, the differentiation between Type A and Type B introduced by the 1991 law has facilitated the organisation of systemic solutions to welfare problems (see Thomas, 2004). Consortia or groups including Type A and Type B cooperatives address a variety of complementary societal goals, from elderly care, to housing, to rehabilitation of psychiatric patients (Type A social cooperatives), as well as work integration in manufacturing, agriculture, and service activities (Type B social cooperatives).

The objective of social cooperatives was to produce welfare services, support employment and, more generally, to produce meritorious goods (Weisbrod, 1988; Bacchiega and Borzaga, 2001). Specialized welfare services and work integration can be considered an example of meritorious goods that can lead to the reduction of social marginalisation. Moreover, because of their "public" aims, social cooperatives have grown to represent specific forms of social enterprise which, in the European tradition places emphasis on social aims, participatory governance, and limited profit distribution (cf. European Parliament, 2012). Democratic membership embodies the participatory requirement, while commercial goals are instrumental to the pursuit of social aims. This emphasis on participatory governance has deep roots in the country's cooperative tradition that had already developed in social service provision prior to the law, as well as in other sectors, such as farming, banking, manufacturing, and retailing.

Moreover, the idea of stakeholder participation was supported by the broader framework set by the Civil Code (art. 2540 and 2542), which regulates representation either through the board of directors or by the institution of multiple assemblies for each of the stakeholders.

Does this mean that in practice all stakeholders have equal authority within the governance structure? It is recognised that in Type A cooperatives the worker interest tends to be dominant. One interesting question is how a model with a prevalence of worker ownership sets out to

Translated by the authors; specifications in brackets [Type A] [Type B] are added by the authors. See Thomas (2004) for more details on Types A and B. 
pursue the interest of users, typically disadvantaged categories of individuals. Social cooperative ownership, in fact, has mainly included workers, volunteers and, less frequently, other non-profit organisations ${ }^{2}$, whilst users have been scarcely represented, especially in Type A cooperatives. So, differently from ordinary cooperatives, social cooperatives-Type A, and to some extent Type Bcannot be considered mutual organisations, since their activities are directed towards the benefit of users rather than the cooperative's main patron (cf. Cafaggi and Iamiceli, 2009).

Type A cooperative statutes tend to emphasise community welfare objectives to be pursued in partnership with public and private organisations. Stakeholders retain control through the assembly, have the right to elect directors and, indirectly, the board president. Having analysed a number of Type A social cooperatives ${ }^{3}$, a possible answer to the question of why workers would pursue users' interests is that although, as a norm, beneficiaries are not owners, their welfare is nonetheless the sine qua non condition for the existence of the cooperative. Because of the social nature and aims of the cooperative project, worker owners understand that their authority is legitimised only if it works for the benefit of vulnerable categories of stakeholder. In other words, there is a binding agreement that ties controlling stakeholders (mostly workers, often paired by volunteers) with non-controlling stakeholders (beneficiaries) ${ }^{4}$.

The answer is different for Type B cooperatives. Type B cooperatives are commercial organisations that design production around work-integration. They seek to develop work opportunities at the best possible conditions for all worker members, including disadvantaged users. In Type B cooperatives beneficiaries of work-integration services should preferably be members (albeit not necessarily). In fact, when hired by a Type B cooperative, users can become worker owners with the same statutory rights of other ordinary worker owners. Where this happens systematically, it provides a way to make users part of the controlling stakeholders. As emphasised by Gui (1991), this double status of workers, as users and member owners, is a special characteristic of B Type social cooperatives. Thus, the welfare of ordinary workers is inexorably related to the presence and welfare of workers with difficulties, since these cooperatives find their reason to exist only if they succeed in integrating users (by law with a proportion of 30:70). With this ownership composition, directors and managers must be clear about their duty, which is to simultaneously maximise the welfare of both type of workers.

In 2006, another piece of legislation instituted the social enterprise model. With the new regulation, the social cooperative form defined in 1991 became just one organisational model among others (including also associations, foundations and other than cooperative businesses). The

\footnotetext{
2 The assembly works with the one-head-one-vote rule, with the exception of members with the status of legal entities (which can express up to five votes), and financial organisations. For the latter, votes cannot go over one third of those attributed to ordinary members, and nomination rights in the board of directors are limited to less than one third (for detailed analysis of the Italian legislation, cf. Cafaggi and Iamiceli, 2009).
}

3 See Sacchetti and Tortia (2014) and Sacchetti (2016) for illustrative cases.

4 On social contract, see Donaldson (1982); Flannigan (1989); Brummer (1991) and Sacconi (2013). 
social enterprise regulation interpreted the participatory governance criterion by requiring openness in the selection of stakeholder members. There are no specific prescriptions on who the members should be, albeit specific attention in the law is dedicated to beneficiaries and workers. In general, it is the social enterprise, through the assembly, that has the right to identify classes of stakeholders ${ }^{5}$. The multi-stakeholder social enterprise can include stakeholders as organisational members or as board members. Through these bodies, stakeholders can contribute to strategic decision-making, including what to produce, and how to distribute economic surplus under the limited distribution constraint. As Borzaga and Mittone (1997) notice, this participative form of governance (paired with a social aim and a non-profit distribution constrain) leads to a unique feature, which is that the activities of the organisation have multiple categories of beneficiaries, including members but also non-members.

This principle was already recognised in 1991 and it had been partly implemented. Even before the 2006 law that instituted a "non-discrimination principle" in relation to stakeholder admission practices, in many instances social cooperatives had put in place solutions for the representation of multiple interests and needs in the form of committees representing beneficiaries or their families (Cafaggi and Iamiceli, 2009).

Despite encouraging pluralism, the 2006 legislation activated other business forms only to a limited extent. Today, the majority of Italian social enterprises is still defined by the social cooperation model, to an extent that the two categories nearly overlap. Workers still remain the main stakeholder to be represented in Italian social cooperatives, but their representation is not exclusive. Borzaga, Depedri and Tortia (2011) have undertaken some research to map the governance status of these organisations. They evidence that nearly $80 \%$ of enterprises providing personal, social and work integration services feature some form of multiple stakeholder involvement. Specifically, one out of three social cooperatives (34\%) are multi-stakeholder, although users are included in the membership in one out of ten social cooperatives. $29 \%$ are hybrid organisations with multiple membership but with a single stakeholder (workers) represented in the board of directors. 16\% have a dual stakeholding (including workers and volunteers), whilst the remaining 21\% are monostakeholder (workers) social cooperatives. Borzaga and Depedri (2015) have further noticed that users are members in the majority of Type B social cooperatives (across sectors, e.g. environmental maintenance, manufacturing), whilst Type A cooperatives (typically providing health assistance and educational services) tend not to involve users.

\footnotetext{
5 Similar requirements were introduced in other countries. However, while Italy introduced a "non-discrimination principle" in the selection of members, France has been the only European country where multi-stakeholding became a specific requirement. The SCIC (Société Coopérative d'Intérêt Collectif) specifies the three types of members that must be represented in the board: workers and beneficiaries, plus a third category to be nominated. Moreover, in France (unlike Italy where the legislator pursued the idea of independence of social enterprises from the public sector) public administrations can also be members of a social enterprise.
} 


\section{To conclude: Some research questions}

Several questions emerge out of this preliminary discussion that might usefully be the focus of further research.

1. A first question concerns sectorial features and especially the role of market structures. Existing analysis has accounted for sectorial features focusing on the meritorious nature of the goods or services provided, but has not provided a comprehensive answer regarding the nature of markets, their competition gradient and its relationship with the governance structure chosen. Are single-stakeholder ownership and governance more likely in highly commercial sectors where competitive pressures are high and market pricing is important? Is multi-stakeholding more likely when the market pressures are lower and prices are set by negotiation with funding agencies such as local authorities?

2. A second issue regards the nature of social care and welfare services, which is the sector where multi-stakeholding is more developed. Economic literature regards the role of third sector organisations in offering welfare services where information asymmetries between producers and users are high (Rose-Ackerman, 1996), but analysis has not fully considered the role of the most appropriate form of private governance under such circumstances. Research could usefully address the following research question: Is multi-stakeholder governance found in social care because it has these specific characteristics: contracts are long-term, service users find it difficult to assess the quality of the product, and the product itself is dependent on the relationship between service provider and user?

3. Thirdly, the relation between ownership and control, when multiple interests are at stake, needs to be further investigated. This paper has pointed at the centrality of strategic control and at the possibility to "distribute" it among stakeholders. But is it possible to operate a multistakeholder governance without bringing more than one stakeholder into ownership? In other words, is ownership less important than we might think? Research could usefully address this question by analysing how legal frameworks can support the protection of multiple stakeholders and the effectiveness of different governance forms, with varying use of ownership.

4. Related to the above, a fourth research question can address the evolution from a single or dual stakeholder structure to the inclusion of multiple stakeholders, and its effects in terms of competitiveness. Is it possible in cooperatives that focus mainly on the needs of one ownerproducer or consumer - to broaden their governance to include other stakeholders? If so, will this provide a business advantage, or will it lead to a loss of focus and higher governance costs compared to those of competitors?

5. The relation between multi-stakeholding and competitiveness effects takes especial relevance in health and social care, where the main contractor is the public sector (Chaney and Fevre, 2001). In some countries (England and Wales for instance) the health and social care sectors are becoming increasingly commercial, with new agencies being formed to bid for contracts. 
Some are multi-stakeholding (mainly workers, service users), some single (usually the workers). In this scenario, which type can we expect to have more success?

6. Sixth, though it is clear that multi-stakeholding is desirable from a business ethics point of view, it is less clear how to ground the idea of shared control from an economic efficiency point of view. Initial contributions have appeared (Borzaga and Sacchetti, 2015; Sacchetti and Borzaga, 2017) opening a novel research line that can usefully address the following question: What are the factors that can lower the internal costs of multi-stakeholding and increase a culture of stakeholder inclusion among directors?

7. Related to the above, is the issue of participation. Multi-stakeholder governance assumes that stakeholders are willing to participate, and that engagement is maintained over time. Research could apply organisational psychology insights to explore, within the multi-stakeholder organisation, what factors contribute to ensure the engagement of stakeholders in collective action.

\section{References}

Bacchiega, A. \& Borzaga, C. (2001). Social enterprise as incentive structures. In: C. Borzaga \& J. Defourny (Eds.), The emergence of social enterprise. London (UK): Routledge, pp. 273-295.

Berle, A. \& Means, G. (1932). The Modern Corporation and Private Property, 10th edition (1991). New Jersey (NJ): Transaction Publishers.

Birchall, J. (1994). Co-op: the People's Business. Manchester (UK): Manchester University Press.

Birchall, J. (2011). People-centred Businesses: Co-operatives, Mutuals and the Idea of Membership. London (UK): Palgrave Macmillan. DOI: https://doi.org/10.1057/9780230295292

Birchall, J. (2013). Finance in an Age of Austerity: The Power of Customer-owned Banks. Cheltenham (UK): Edward Elgar. DOI: https://doi.org/10.4337/9781781951842

Birchall, J. (2014). The Governance of Large Co-operative Businesses. Manchester (UK): Co-operatives UK.

Borzaga, C. \& Depedri, S. (2015). Multi-stakeholder Governance in Civil Society Organizations: Models and Outcomes. In: J.L. Laville, D.R. Young \& P. Eynaud (Eds.), Civil Society, the Third Sector and Social Enterprise. Abingdon (UK): Routledge, pp. 109-121.

Borzaga, C., Depedri, S. \& Tortia, E.C. (2011). Testing the distributive effects of social enterprises: the case of Italy. In: L. Sacconi \& G. Degli Antoni (Eds.), Social Capital, CorporateSocialResponsibility, Economic BehaviourandPerformance. New York (NY): Palgrave Macmillan, pp. 282-303. DOI: https://doi.org/10.1057/9780230306189_11

Borzaga, C. \& Mittone, L. (1997). The multi-stakeholders versus the non-profit organisation. Discussion Paper, 7/1997, University of Trento (Italy), Department of Economics.

Borzaga, C. \& Sacchetti, S. (2015). Why social enterprises are asking to be multi-stakeholder and deliberative: an explanation around the costs of exclusion, Euricse Working Papers, 75|15. DOI: http://dx.doi.org/10.2139/ ssrn. 2594181

Briscoe, R., McCarthy, O. \& Ward, S. (2012). From co-operatives to conventional businesses and back again; the Irish co-operative experience. In: J. Sousa \& R. Herman, A Co-operative Dilemma: converting organisational form. Saskatchewan (Canada): Centre for Study of Co-operatives.

Brummer, J. J. (1991). Corporate responsibility and legitimacy: an interdisciplinary analysis. New York (NY): Greenwood Press. 
Cafaggi, F. \& Iamiceli, P. (2009). New frontiers in the legal structure and legislation of social enterprises in Europe: A comparative analysis. In: A. Noya (Ed.), The Changing Boundaries of Social Enterprises. Paris: OECD, pp. 25-87. DOI: https://doi.org/10.1787/9789264055513-3-en

Chaney, P. \& Fevre, R. (2001). Inclusive governance and "minority" groups: the role of the third sector in Wales, Voluntas, 12(2): 131-156. DOI: https://doi.org/10.1023/A:1011286602556

Cowling, K. \& Sugden, R. (1998). The Essence of the Modern Corporation: Markets, Strategic Decision-Making and the Theory of the Firm, The Manchester School, 66: 59-86. DOI: https://doi.org/10.1111/1467-9957.00089

Defourny, J. \& Nyssens, M. (2017). Fundamentals for an International Typology of Social Enterprise Models, Voluntas, 28: 2469-2497. DOI: https://doi.org/10.1007/s11266-017-9884-7

Donaldson, T. (1982). Corporations and Morality. Englewood Cliffs (NJ): Prentice Hall.

Ellerman, D. (1990). The Democratic Worker-owned Firm. Boston (MA): Unwin Hyman.

Eroski (2015). Annual Report. Available at: http://www.eroskicorporativo.es/sites/default/files/eroski-annual-report2015-english.pdf [Accessed: December 2018]

European Parliament (2012). Report on Social Business Initiative - Creating a favourable climate for social enterprises, key stakeholders in the social economy and innovation (2012/2004 (INI)), Committee on Employment and Social Affairs. Available at: http://www.europarl.europa.eu/sides/getDoc.do?type=REPORT\&reference=A7-20120305\&language=EN [Accessed: January 2017]

Fici, A. (Ed.) (2018). La riforma del terzo settore e dell'impresa sociale. Naples (Italy): Editoriale Scientifica.

Flannigan, R. (1989). The fiduciary obligation, Oxford Journal of Legal Studies, 9: 285-294. DOI: https://doi.org/10.1093/ ojls/9.3.285

Gui, B. (1991). The economic rationale for the third sector, Annals of Public and Cooperative Economics, 62(4): 551-572. DOI: https://doi.org/10.1111/j.1467-8292.1991.tb01367.x

Hansmann, H. (1996). The Ownership of Enterprise. Cambridge (MA): Harvard University Press.

Hymer, S. (1972). The Internationalization of Capital, Journal of Economic Issues, 6 (1): 91-111. DOI: https://doi.org/1 $0.1080 / 00213624.1972 .11503013$

iCoop (2015). Annual Report. Available at: http://icoop.coop/?page_id=7966377\&ckattempt=1 [Accessed: December 2018]

Italian Parliament (1991). Law No. 381 of 8 November 1991, Disciplina delle cooperative sociali.

Jensen, M., \& Meckling, W. (1976). Theory of the Firm: Managerial Behavior, Agency Costs, and Ownership Structure, Journal of Financial Economics, 3: 305- 360. DOI: https://doi.org/10.1016/0304-405X(76)90026-X

Kirkpatrick, G. (2009). The Corporate Governance Lessons from the Financial Crisis, Financial Market Trends, 1/2009, Paris: OECD.

Rose-Ackerman, S. (1996). Altruism, Nonprofits, and Economic Theory, Journal of Economic Literature, 34 (2): 701-728.

Sacchetti, S. (2016). Governance for a "Socialised Economy". A Case Study in Preventive Health and Work Integration, Euricse Working Papers, 89|16. DOI: http://dx.doi.org/10.2139/ssrn.2891313

Sacchetti, S. \& Borzaga, C. (2017). The Foundations of the "Public" Organisation: Strategic Control and the Problem of the Costs of Exclusion, Euricse Working Papers, 98|17. DOI: http://dx.doi.org/10.2139/ssrn.3095525

Sacchetti, S. \& Tortia, E.C. (2014). The social value of multi-stakeholder co-operatives: The case of the CEFF system in Italy. In: T. Mazzarol, S. Rebooud, E.M. Limnios, \& D. Clark (Eds.), Research Handbook on Sustainable Cooperative Enterprise: Case Studies of Organisational Resilience in the Co-operative Business Model. Cheltenham (UK): Edward Elgar, pp. 285-302. DOI: https://doi.org/10.4337/9781783472024.00025

Sacconi, L. (2013). The Economics of corporate social responsibility. In: S. Zamagni \& L. Bruni (Eds.), Handbook on the economics of reciprocity and social enterprise. Cheltenham (UK): Edward Elgar, pp. 372-399. DOI: https://doi.or g/10.4337/9781849804745.00046 
Thomas, A. (2004). The rise of social cooperatives in Italy, Voluntas, 15: 243-263. DOI: https://doi.org/10.1023/ B:VOLU.0000046280.06580.d8

Turnbull, S. (2001). The competitive advantages of stakeholder mutual. In: J. Birchall, (Ed.), The New Mutualism in Public Policy. London (UK): Routledge. DOI: https://doi.org/10.4324/9780203470565.ch9

Weisbrod, B. (1988). The non-profit economy. Cambridge (MA): Harvard University Press.

Young, D., \& Lecy, J. (2014). Defining the universe of social enterprise. Competing Metaphors. Voluntas, 25(5): 13071332. DOI: https://doi.org/10.1007/s11266-013-9396-z

Zeitlin, M. (1974). Corporate Ownership and Control: The Large Corporation and the Capitalist Class, American Journal of Sociology, 79 (5): 1073-1119. DOI: https://doi.org/10.1086/225672

Zingales, L. (1995). What Determines the Value of Corporate Votes?, Quarterly Journal of Economics, 110: 1075-1110. DOI: https://doi.org/10.2307/2946648 